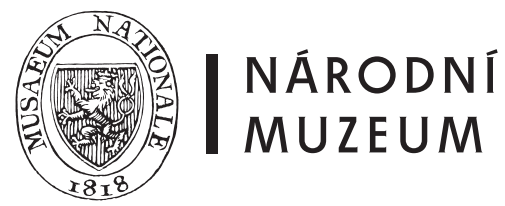

\title{
TÉMA
}

\section{KNIŽNÍ KULTURA 19. STOLETÍ}

Otázku „,co je historie knihy“ položil Robert Darnton v atmosfére měnících se paradigmat ve společenských a humanitních vědách v 2. polovině 20. století. Hledání odpovědi na Darntonovu otázku postupně vyústilo v preferované mezioborové pojetí výzkumu knižní kultury. Diskurz dějin knihy se posunul od bibliografického zázemí s důrazem na materiální povahu textu směrem ke studiu kulturních, sociálních, ekonomických a právních kontextů. Rovněž se stalo samožrejmostí věnovat pozornost samotné knize jako solitérnímu a plně autonomnímu estetickému objektu jak v prostředí vizuální kultury, tak v mediálních studiích. Současné výzkumy, studie a dílčí monografie, rovněž setkávání odborníků k problematice knižní kultury 19. století reagují na podněty dynamicky se rozvíjejícího oboru v mezinárodním měřítku.

Téma - různé aspekty domácí knižní kultury 19. století - je natolik rozsáhlé a komplikované, že také toto monotematicky zaměřené číslo časopisu Acta Musei Nationalis Pragae - Historia litterarum může obsáhnout jen dílčí problémy a vybrané kapitoly „dlouhého“ století a zaplnit pouze částečně mezeru v neexistujících dějinách české knižní kultury tohoto období. Soustavné zpracování dějin knižní kultury 19. století dosud nahrazují jednotlivé studie, diplomové a disertační práce, kapitoly v odborných knihách a monograficky zpracovaná dílčí témata. Odborná veřejnost proto se zájmem očekává vydání každé další publikace,
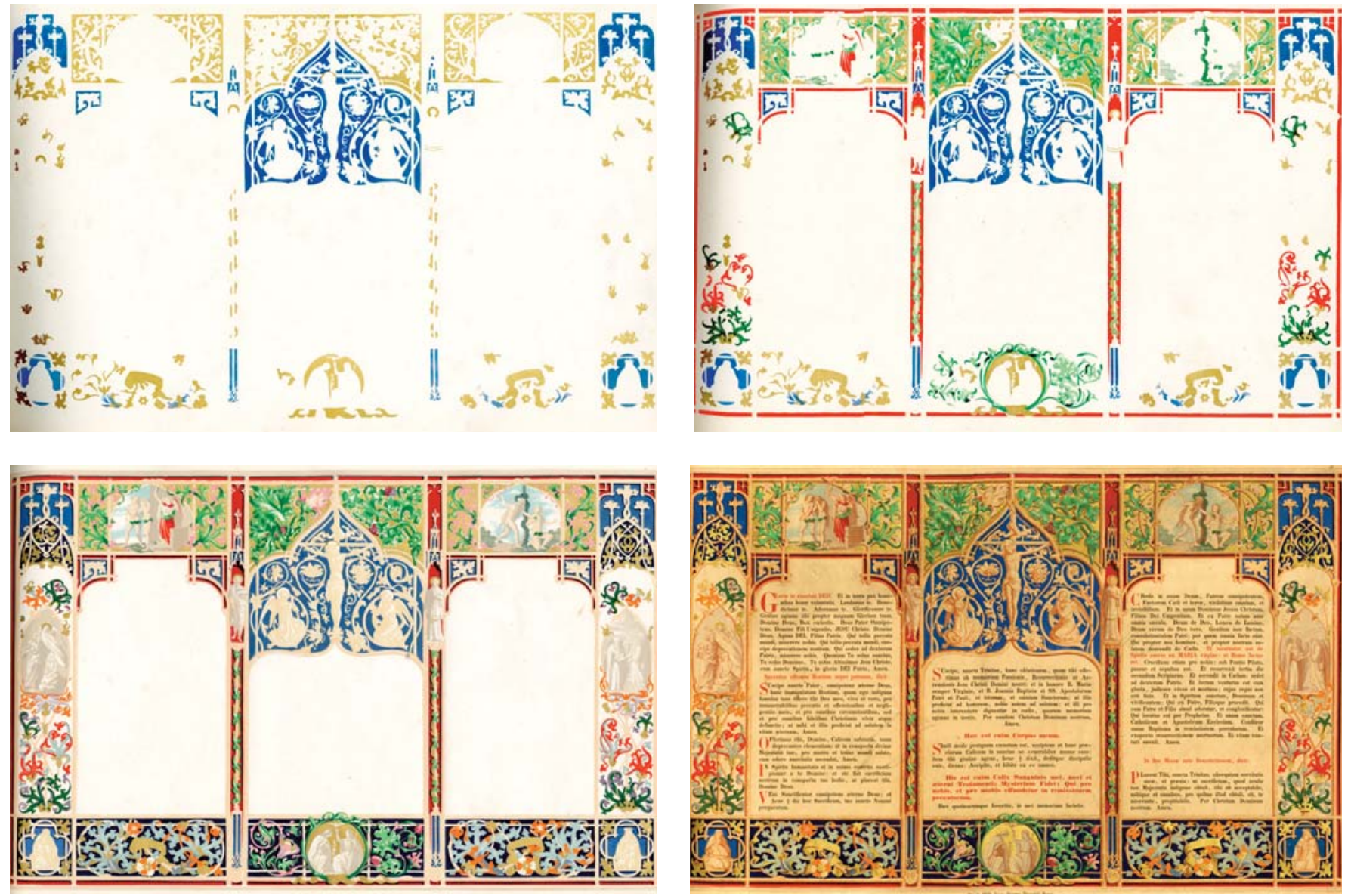

Obr. 1-4. Ukázka postupného soutisku jednotlivých tiskových barev a textu z celkem 23 štočků (tiskových desek), použitých při tisku křestaanského kánonu v tiskárně Gottlieb Haase Söhne, Praha, 1850. KNM, inv. č. NAOF B. Haase 722. 
která rozššří naše poznání. V nejbližší budoucnosti to budou výsledky grantového projektu Ústavu pro českou literaturu AV ČR „Budování národa čtenářro: sítě, podniky a protagonisté knižního trhu v Čechách (1749-1848)“.

Devatenácté století je třeba vnímat jako období přechodu od tradiční civilizované společnosti „knihy“k postgutenbergovské civilizaci, popsané a analyzované McLuhanem. V kontextu všeobecného růstu to byla doba kontrastů a kolizí. V oblasti knižní kultury se projevil vliv nových technologií v kvantitativním růstu čtenářủ vyúst'ující v masové čtení. V oběhu knihy se objevily nové, diferencovanější profese (nezávislí spisovatelé, nakladatelé, čtenářská veřejnost) a ve výrobě knihy nové struktury (nakladatelské domy, distribuční firmy, tiskárenské podniky). Podstatně se zkrátil proces od vzniku textu přes výrobu knihy až po jeho recepci. Distribuci ovlivnily nové komunikační možnosti, díky kterým se dařilo překonávat čas a prostor, rovněž se objevily dosud neznámé zpo̊soby distribuce (nap̌r. prodej knih v síti nádražních stánků). Knihtisk se postupně stal výnosnou komoditou. S rostoucí nabídkou novin a časopisů se profesionalizovala role autora a literární vlastnictví se rovněž stalo výnosnou komoditou. Nakladatelé využili toho, že zcela nový fenomén - čtení jako volnočasová aktivita - zvedal náklad novin a časopisů a zároveň sloužil jako reklama pro zvýšení prodeje beletrie a naučné literatury. Seriály se staly běžnou součástí literárních periodik, a v posledních dekádách 19. století romány na pokračování (at’ legální či pirátské kopie) kolovaly rovněž na mezinárodním poli. Nová odbytiště pro literární texty v periodickém tisku vyžadovala systematičtější organizaci tiskové produkce i souvisejících profesí. Postupně byla zakládána profesní sdružení pro všechny významné segmenty knižního trhu, jejichž úkolem bylo hájit jejich specifické zájmy (sdružení knihkupců, nakladatelů, autorů, tiskárenských dělníků atd.).

Obecné jevy charakteristické pro 19. století - industrializace, nové ekonomické a společenské infrastruktury, demokratizace př́stupu ke vzdělání a zábavě, podoba rychle rostoucích měst výrazně poznamenaná reklamou - se projevovaly rovněž v českých zemích, avšak často se zpožděním. Pomalejší tempo zprůmyslňování (modernizace jednotlivých odvětví podílejících se na výrobě knihy) ovlivňovaly např. archaické finanční struktury, blokující rozvoj tržních mechanismů. Specifický jev - jakým bylo např. národní obrození, jehož programem bylo v rané fázi obnovit jazykově českou kulturu - vyústil v potřebu definovat „národní publikační strategii“", která by pomohla domácím podnikatelům obstát v konkurenci německých knihkupců a nakladatelů. K úkolům současné knihovědy tedy rovněž patří rekonfigurovat zažité a širší veřejností přijímané stereotypy (např. interpretace jazykově německé kultury) a na základě analýzy knižní produkce interpretovat vliv knihtisku na utváření společenského diskursu a národních identit.

V předkládaném čísle zaměřeném na knižní kulturu 19. století, jsou představeny víc než dvě desítky studií jak z oblasti literární a vizuální kultury, tak z oblasti výroby a distribuce knihy včetně čtenářství. Ve většině př́padů se jedná o publikování dílčích úzce zaměřených studií. Účelem této předmluvy není představit jednotlivé příspěvky čísla, ale vyzdvihnout heuristický prrínos všech příspěvků a uvést alespoň jeden, který zohledňuje různorodá hlediska při zpracování tématu. Příspěvek věnovaný produkci Landfrasovy tiskárny a nakladatelství v 19. století přibližuje oblast knihtisku a nakladatelského podnikání komplexněji. Rodinný podnik Landfrasů, který byl založen na samém konci 18. století, je př́íkladem úspěšného podnikání v podmínkách českého venkova. Představuje ideální způsob akumulace kapitálu, jeho investování do modernizace výroby a zároveň schopnost spolupracovat v rámci regionu, ale rovněž mimo něj s redaktory, překladateli, autory i distributory. Na úspěšném podnikání Landfrasů měla jistě podíl nakladatelská strategie majitelů, zvláště pak tvořivě rozpracovaná distribuční praxe Krameriovy České expedice.

Landfrasovské tisky představují typ tradičního venkovského knihtisku, orientovaného na konkrétní čtenářské skupiny. Typografické kvalitě těchto tisků je věnován příspěvek, ve kterém jsou na základě analýzy písem užívaných v Landfrasově tiskárně kriticky zhodnocena lomená písma a sady antikvových písem. Kromě brilantní typologie písem autor reflektuje písmo jako určitou kulturní hodnotu a jako vizuální znak zachycující pohyb a změny ve společnosti. Oba uvedené př́spěvky - rámcová kapitola a př́ípadová studie se jeví jako jedna z již prověřených možností, jak koncipovat naše dějiny knižní kultury.

Mgr. Alena Petruželková 